\title{
A History of Italian Citizenship Laws during the Era of the Monarchy (1861-1946)
}

\author{
Luca Bussotti 1,2,3 \\ ${ }^{1}$ International Studies Centre, ISCTE/IUL, Lisbon, Portugal \\ ${ }^{2} \mathrm{CEC}$ (Centro de Estudos Interdisciplinarers de Comunicação), Maputo, Mozambique \\ ${ }^{3}$ ISGE-GM, Marracuene, Mozambique \\ Email: labronicus@gmail.com
}

How to cite this paper: Bussotti, L. (2016). A History of Italian Citizenship Laws during the Era of the Monarchy (1861-1946). Advances in Historical Studies, 5, 143-167. http://dx.doi.org/10.4236/ahs.2016.54014

Received: August 12, 2016

Accepted: September 9, 2016

Published: September 12, 2016

Copyright $\odot 2016$ by author and Scientific Research Publishing Inc. This work is licensed under the Creative Commons Attribution International License (CC BY 4.0).

http://creativecommons.org/licenses/by/4.0/ (c) (i) Open Access

\begin{abstract}
This article aims to present the evolution of Italian citizenship from political unification to the end of the Second World War, which in Italy corresponds with the end of the monarchy and the advent of the Republic. In this long period, the central definition of Italian citizenship was given by the Civil Code (1865), the basis of which was Ius sanguinis and the patrilineal system. The 1912 Law on Citizenship changed some aspects of the previous legislation, but did not alter the general legal scenario, despite great pressure from some organised movements such as those formed by Italian expatriates in the Americas. With the advent of fascism (1922), the discourse on the Italian nation became radicalised, but Mussolini's regime did not pass any organic laws on citizenship. The innovations introduced under fascism were relatively modest; many were directed towards limiting the rights of particular categories of citizens, such as political opponents and Jewish people. Italy reached the beginning of the republican period with a legal apparatus on citizenship that was very similar to the one established for the first time in the Civil Code of 1865. This shows how Italian political classes have given more attention to the orthodoxy of the law than to the need to adapt it to the numerous transformations in Italian society.
\end{abstract}

\section{Keywords}

Italian Citizenship, Nation, Fascism, Legal Innovation

\section{Introduction}

This work does not have philosophical objectives: in particular, it does not want to consider the ancient and complex debate on the concept of citizenship, maybe one of the most important of Western thought since the Greeks onwards. So, the article will not 
discuss the various conceptions of citizenship before the period here approached, focusing its analysis on a historical, juridical and political perspective.

The main objective is thus to analyse the evolution of Italian citizenship during the era of the monarchy, from the foundation of the Italian Kingdom (1861) to the referendum which, after the end of the Second World War in 1946, replaced the monarchy with the Republic as the new form of state for Italy.

Its main thesis is that a line of continuity has crossed Italian right on citizenship in this long period, even if during Fascism (1922-1943) some transformations has occurred, especially in terms of general conception rather than of actual change of citizenship law.

The European context, throughout the $18^{\text {th }}$ century, was extremely dynamic, as from a political as from a juridical point of view. After the French Revolution and the Restauration, many States experienced new social movements, whose aim was to obtain the political independence or the reduction of monarchic power. The first country to reach this goal (from the Ottoman Empire) was Greece, meanwhile, after the Congresses of Troppau (1820) and Ljubljana (1821), the revolts in Italy, Portugal and Spain suffered a strong military repression, under the impulsion of Metternich. However, in Spain the new Constitution of Cadiz (1812) began to be a symbol of progression and democracy, giving a vast political space to the bourgeois, through the Low Chamber. In the Thirties, Belgium obtained its independence, and in France the old king, Karl X, was deposed, in favour of Louis Philippe d'Orleans. The revolts of 1848 were even more violent and well organized: they interested the most important European countries, as Great Britain, France, Italy and the German galaxy of States, yet not unified in a unique political entity (Costa, 2005).

Various States which composed the political mosaic of the pre-united Italy approved too new Constitutions (as the Sicilian one in 1812): however, especially after the revolts of 1848, many of them came back to their decisions, and cancelled a great part of the concessions which had been made. In the Rein of the Two Sicilies, for instance, Ferdinand the $2^{\text {nd }}$ of Bourbon, after having sustained militarily the attempt of the Piedmont State to fight against the Austrian-Hungary Empire in Lombardy and Veneto, called back his troops and abolished the Constitution, revoking the Neapolitan Parliament; in the Vatican State the situation was yet worse than in the South: the Pope went into a voluntary exile to Gaeta, leaving his State to the Roman people. So, a new Republic was elected and a new, advances Constitution approved (in July, the $3^{\text {rd }}, 1849$ ). French troops stopped abruptly this experience, supporting the Pope. In Tuscany the situation was very similar: here too, Leopold the $2^{\text {nd }}$, the Gran-Duque, left Florence, coming back only thanks to the militarily intervention of the Austrian troops. The Statute which had been conceived decayed in 1852 .

All these experiences, together with other very similar which was occurring in Europe, left, as their legacy, the idea that the popular classes (especially the bourgeois) had the right to actively participate to the political life, promoting a new conception of citizenship. Nevertheless, for the Italian scenario, these impulses were not sufficient to 
promote a unification under Republican bases: in fact, to think Italy could obtain its unification through a federal process vanished, so that the only actual alternative was a process conducted by Savoy's Royal House, with a very moderate political and constitutional approach (Migliacci, 2011).

The question of citizenship was not one of the first concerns of the new Italian State.

So, the bases of Italian citizenship have to be found in the Civil Code, approved in 1865, after a long work of harmonization of the previous, backward Constitutions of the different pre-united States (Codice Civile Italiano, 1865). It is here that Italian legislator tries to define the essence of the new Italian citizen: who is he, how can he acquire or lose his citizenship, which laws regulate the relationships between husband and wife inside family in terms of citizenship and so on (Donati, 2013).

Their key principles were the adoption of Ius sanguinis for the determination of citizenship by birth, the uniqueness of Italian citizenship (excluding dual citizenship), the patrilineal system of transmission, linking wives' citizenship to their husbands' citizenship, and finally the freedom of decision regarding which citizenship could be chosen in the event of conflict between two citizenships. Through these principles, the Italian legislators intended to distinguish "its" citizens from citizens of all other countries. At this stage, the number of citizens was not as important as the "quality" of the citizens and their fidelity to the Italian cause.

Law no. 555/1912, the first organic law of Italian citizenship, maintained the same key principles and contained few modifications in relation to the Civil Code of 1865. Paradoxically, Law no. 555/1912 was more important for what it did not state than what it did. At that time, a huge flow of Italians migrated to the Americas, especially the United States and Argentina. Many of them acquired the citizenship of their hosting states. Important movements formed of Italian migrants began to make claims in favour of the dualnationality. The Italian legislators, composed mostly of moderate politicians and (especially at the Senate) many lawyers, dramatically rejected this proposal and continued to prefer a "pure" Italian citizen to a "shared" one.

The peace agreements of the First World War complicated the legal landscape depicted above because a series of new provisions were inserted in every treaty, starting with the protection of minorities whose territories had been incorporated for the first time into Italian territory, as in the case of Alto Adige.

When fascism came to power, its philosophy was completely different from the one expressed by "liberal Italy" (Romanelli, 1979) and by the peace treaties. Mussolini had a clear idea of what Italian citizenship should represent: a number, possibly a large one, in order to challenge other European states on a military field. The minister Rocco presented a draft law to the Parliament but was unsuccessful. So, the only law on citizenship approved by fascist institutions, therefore, was Royal Decree no. 1997/1934. It was an extremely simple law comprising only two articles, essentially designed to favour the acquisition of Italian citizenship by foreigners who were regularly resident in Italy.

Fascism had an important role in the history of Italian citizenship, especially for the restrictions it imposed on special categories of citizens and the introduction of the 
"colonial right". In this case, the result was a variety of types of Italian citizenship: colonial citizenship (for Libyan inhabitants), subjects of the Kingdom (for Eritrean and Somali inhabitants) and Italian citizens in general, with political and racial restrictions.

These restrictions were directed towards political enemies (Law no. 108/1926 and Royal Decree no. 16/1926) and, in their final stage (Royal Decree no. 1728/1938), Jewish Italian citizens.

This article has four sections: the first analyses the foundation of Italian citizenship; in the second one, the focus is on Law no. 555/1912; the third section is devoted to the effects of the post-First World War international treaties on Italian citizenship; in the last one, particular attention is paid to the new laws fascism introduced to Italian citizenship law.

In terms of methodology, a mixed approach is used: historical reflection prevails, trying to relate changes in the law to social movements and the debate inside and outside the Italian Parliament. The transformations of Italian citizenship law considered here are framed within a historical and social perspective. This methodology should make it possible to completely view the evolution of Italian citizenship and its main steps and innovations.

A last note on concepts: in this article, the terms "citizenship" and "nationality" are used synonymously, since this distinction was not present in Italian law. The distinction is only present in the fascist period, since the regime tried to differentiate between the two legal statuses. No philosophical or sociological references are made to the concept of "citizenship" as formulated, for instance, by Marshall and his commentators.

\section{The Foundation of Italian Citizenship: Main Principles and Problems in the Italian Civil Code (1865)}

The first formulation of Italian citizenship law has its roots in the "Italian moderate revolution" led by Cavour, through which Italy became an independent country in 1861. At the moment of unification, one of the main problems Italy had to tackle was the question of citizenship.

The configuration of the new state-its principles, its rules, its ways of involving (or rather, excluding) the masses from political life-responded to conservative ideas (Riall, 1994).

It was difficult to establish who should be considered an Italian citizen. The preunited states had their own civil codes with specific laws. There were five main ones at the time: the Austrian code, approved in 1815, the code of the Kingdom of Two Sicilies (1819), the Parma code (1820), the Modena code (1831), and finally the Subalpine code (1837). Tuscany did not have a civil code, since common law prevailed there (Bussotti, 2002). In addition, a framework of decrees, specific laws, and exceptions to the main rules in all the Italian pre-united states had caused a chaotic situation: weddings, contracts, citizenship, and all the issues related to civil life encountered different regulations in different states. No one could imagine bringing all these legal traditions together without an enormous effort. 
Therefore, there were two problems related to the question of citizenship: firstly, was it necessary to put a specific rule in the new Italian Constitution or Statute or was it enough to insert a rule into the new Civil Code? Secondly, how was Italian citizenship to be determined?

The first question was resolved by the adoption of the Albertine Statute for the new Italian Kingdom. This Statute had been approved in 1848 by the Subalpine Kingdom and signed by King Carlo Alberto of Savoy. The new Italian ruling class (which came mostly from the Subalpine Kingdom) decided to extend the old Subalpine Statute across the country.

Nevertheless, citizenship was not one of the issues dealt with by the Civil Code. There was a section devoted to citizens' rights and duties, but it did not give any definition of who was considered Italian. This lacuna needed to be filled. The only legal instrument that could do so was a new civil code.

The second question emerged at a time when a vast group of experts began to reflect on the future civil code of the Italian state. As Bollati showed, the moment in which the need to define Italian identity arose was the period at the start of the unification process (Bollati, 1983). Nevertheless, in this case, the choice was completely different from what had happened in relation to the Statute. A new civil code now had to be written. The revision of the new Civil Code ended in 1863, when the Minister of Justice of the Italian Kingdom, Pisanelli, presented the three volumes to the Senate for discussion and approval (Calcaterra, 1873). His successor, Vacca, found the work and he submitted the "Pisanelli Code" to Parliament for approval. As he mentioned in his parliamentary report, the new Civil Code needed to respond to the desire for the "full development of the country's legal culture" (CD, 1865: p. 6).

The Civil Code of 1865 addressed the topic of citizenship in its first book, "Delle Persone". In particular, it defined those who should be considered citizens, determining the conditions for the acquisition and loss of this status. The main issues that found a solution were the following:

1) The adoption of Ius sanguinis: citizenship was to be transmitted by the patrilineal system. Article 1(4) said: "A citizen is the child of a father who is a citizen". This principle could be attenuated through some concessions to Ius soli or the mother's citizenship in some specific cases. These cases included: a) If the father lost his Italian citizenship before the baby was born, while resident abroad: in this case, the new-born could not be considered Italian. However, if the father was in this situation but the baby was born in Italy and resided there, then he/she was Italian (Article 5); b) If the father was unknown and the mother was Italian, the new-born was Italian too. If both parents were unknown, the Ius soli principle substituted the Ius sanguinis principle entirely: those born in Italian territory whose parents' identity was unknown (namely in the cases of damnato coitus) were Italian (Article 7); c) Those was born in Italy to a foreign father were considered Italian if the father had resided in Italy for more than 10 years, and they had the opportunity not to choose Italian citizenship once they reached the age of majority (Article 8). 
2) The idea of the family as a homogeneous nucleus, in which it was impossible for members to have different citizenships. In this case, the wife always had to accept the citizenship of her husband, and the same applied to their children. This is particularly interesting in relation to the conditions for losing or acquiring Italian citizenship and when the father recognised paternity with some delay. If the husband and wife came from different nations, the foreign woman acquired Italian citizenship and kept it even after the death of her husband (Article 9). Only the children could choose a nationality that was not Italian when they reached the age of majority. In the case of delayed recognition of the child by the father, even when the mother had transmitted her nationality to her child, the child would lose the mother's nationality and acquire the father's one instead.

3) The exclusivity of Italian citizenship, which made it impossible to have two nationalities. In fact, one of the reasons for losing Italian citizenship was obtaining a different nationality abroad or to have accepted, without the authorisation of the Italian Government, to work for a foreign state or to have served in the army of a foreign political power (Article 11). If the head of a family lost his Italian citizenship due to the above-mentioned reasons, all the other family members had to follow this change. They could only keep Italian citizenship if they continued to reside in Italy. The exclusivity of Italian citizenship also applied to reacquisition: in fact, it was possible to reacquire it if the head of the family gave up his foreign nationality and his work or service in a foreign army and established residence in Italy within one year from the declaration made before an Italian civil servant (Article 13). Similarly, an Italian woman who married a foreigner became a foreigner when she acquired her husband's nationality. Once she had become a widow, she would be able to reacquire Italian nationality if she returned to Italy within one year. As some scholars pointed out, the condition of woman in Italian legislation, namely the one related to citizenship and civil and political rights, was unequal in comparison with the condition of man: only after the Second World War, with the advent of the Republican regime and a new Constitution (19489, woman will begin to move the first, meaningful steps for equalizing her rights of citizenship with the rights of the man (Rossi-Doria, 1996; D’Amelia, 2006).

4) The impossibility of being stateless. As seen in the cases mentioned above, the Italian Civil Code never allowed people to become stateless. This was relevant for the nationality of women who had married a foreign man and could therefore lose their nationality. The Code paid particular attention to ensuring that she would not be left without any citizenship.

5) The distinction between "lesser" and "greater" or "full" nationality: Article 10 of the Civil Code distinguished between citizenship "acquired by law" or "by royal decree" and citizenship acquired "by choice". For acquisition by law, a "natural" citizen could enjoy all rights, including political rights; citizens "by choice" were excluded from political rights.

The approval of Civil Code gave rise many comments, which highlighted the issues raised. In brief, the following three main points were raised: 
1) The adoption of Ius sanguinis reflected the prevalent cultural and political leanings of the time (Salvatorelli, 1975). Leftist tendencies, such as those inspired by Mazzini, defended Ius sanguinis because of the importance of the homeland as a bridge between humanity and individuals. "Without a Homeland (...) you are a bastard of Humanity” (Mazzini, 1860: pp. 51-65). Influenced by Herder, Mazzini and his followers could not adhere to Ius soli. Pasquale Stanislao Mancini, for example, defended the "right of people" over the right of states, so that there was no space for Ius soli (Mancini, 1851: p. 44). The right-wing or moderate movements shared the same ideas, accentuating blood rather than cultural factors as the main component for national unity. Gioberti, the leader of Neo-Guelphism, spoke of an "Italian ancestry bound by blood, religion, written language" (Gioberti, 1846: pp. 117-118), while a very important scholar of the period, Sechi, emphasised that nationality was a "matter of race" and that "the various races are transmitted by blood and do not depend on the case of birth" (Sechi, 1897-1902: p. 221). The same debate at the Italian Parliament showed that the defenders of Ius soli represented a small minority. In fact, while Pisanelli pointed out that "race is the primary element of nationality", the only one who tried to oppose was Crispi, who took the side of Ius soli. For him, "citizenship is given by the land in which one was born; each individual who was born in the Italian Kingdom is an Italian citizen" (Gianzana, 1888). This idea was used to put forward the medieval position that the land was the most important link between a nation and its subjects (Borsari, 1871: p. 150 ). In Italy in the $19^{\text {th }}$ century, the young, new nation had to root itself in the most physical of elements-blood-and relegate land to a secondary position.

2) The prevalence of the patrilineal system also encountered some opposition. The debate that took place was between two different philosophical and cultural positions and had a direct influence on the Civil Code: some defended the unity of family as the basis of Italian society, the nation and, consequently, citizenship law; others wanted to radicalise freedom of choice, leaving everyone free to opt for Italian or foreign citizenship regardless of sex. The report to the Senate that accompanied the part of Civil Code related to citizenship law was clear: "A free homeland wants free children and not servants (...). Thus (...) the proposal allows for freedom to give up nationality and leave the homeland for those who have an overbearing need, due to serious incidents or hope for a better future under another sky" (Gianzana, 1888: p. 165). However, it is easy to see that this statement contradicted the idea that wives and children automatically followed the head of their family's nationality, excluding any chance to freely choose a different nationality. In this case too, two opposing positions emerged. In general, the position of women in Italian culture in the $19^{\text {th }}$ century followed a highly antiquated model; the legal system was consistent with this conviction. Women were given permission to enter high schools and universities in 1874 . Only in 1919 were they given formal emancipation from their husbands and fathers, with the abolition of marital authorisation to manage their own belongings and testify in a trial. And only in 1922 were they given the right to vote in local elections, although fascism revoked this right entirely in 1929. The issue that needed to be faced was the following: which principle 
would prevail in citizenship law? The family or the individual? There were a few doubts in the debate at the Italian Parliament. Once more, representatives of progressive positions, like Mancini, expressed the same opinions as other, more moderate exponents, like Ricci. All concluded that the state was "an aggregate of families" and that the relationship between state and individual was mediated by family (Mancini, 1851; Ricci, 1891). This statement had a direct effect on public rights, since ties had to be founded on the family and not on individual rights.

3) Italian citizenship had to be exclusive: this meant that dual nationality could not be permitted. The same ideological apparatus that defended Ius sanguinis served to justify the decision not to accept dual nationality in the Italian Civil Code. When it was approved, in 1865, the migratory flow from Italy to other countries had not yet reached significant proportions and, more importantly, it was not considered to be a mass phenomenon. The 1861 general census indicated that consistent groups of Italians could already be found in France (77,000), Germany and Switzerland (14,000), and in the major Mediterranean African countries, such as Egypt and Tunisia. There were about 1 million Italian residents in the Americas, half of whom were living in the United States. Nevertheless, until the 1880s, Italian migration continued to be relatively sporadic and not systematically organised, with an average flow of around 135,000 people. Between 1887 and 1900, this flow doubled, reaching 269,000 people per year. This new social situation had an immediate impact on the debate about citizenship. Italian citizens who lived abroad began to organise associations, and they were particularly active in claiming continued Italian citizenship, even after obtaining the nationality of the host state. The Italian Civil Code left some ambiguities in relation to the loss of citizenship if a migrant had obtained the nationality of his/her new state of residence. The individual's declaration regarding his/her citizenship always prevailed. Article 11(2) therefore had to be interpreted correctly. Italian citizenship was lost "by those who had obtained the citizenship of a foreign country" after moving their residence there. Some interpreted this article literally: an individual would lose his/her Italian citizenship as soon as another nationality was acquired. Others, however, thought that the interpretation was not correct, since in some cases attribution of a new nationality was automatic, regardless of what the person wanted. In these cases, Italian citizenship should be conserved. Ambiguities emerged even in cases that appeared to be clearly regulated by the Italian Civil Code. For instance, it was undisputed that someone who served in a foreign military force would lose his Italian nationality. However, if the military service was in the Civil Guard of the municipality in which the Italian citizen resided, he could avoid losing his original nationality. In light of this, the Supreme Court of Rome issued a judgment in favour of maintaining Italian citizenship, originating a case of dual nationality (Appello Roma, 1877: p. 304). Some, considering the new social situation, began to reflect on how this contradiction could be solved. Esperson, for example, pointed out that the adoption of Ius sanguinis created an irreconcilable contrast with the adoption of a pure Ius soli principle by several American countries where many Italians lived (Esperson, 1883). These ambiguities reinforced the pressure that Italian migrant organisations 
were placing on the principle of uniqueness of citizenship. During the First Congress of the Italian Expatriates, in 1908, organised by the Italian Colonial Institute (ICI), founded in 1905, this issue emerged with full force. Senator Giacomo De Martino, one of the founders of the ICI and President of the 1908 Congress, declared that the Italian state had to stop being an "almost passive spectator" of migratory flows and reach out to "our brothers who are losing their nationality" (ICI, 1908: p. 11). De Martino did not put forward any concrete proposals but he clearly stated that dual citizenship had to be introduced into Italian law. De Martino was a nationalist and colonialist and, unlike Professor Buzzati, a democrat. He formulated a more explicit proposal in favour of instituting dual citizenship (Idem). A very similar position was defended by a moderate advocate, Valli, during the Congress of the Dante Alighieri Association, in 1909.He tried to distinguish between nationality (the original "ethnic" citizenship that belonged to the individual) and citizenship (a transitory condition, which the individual would lose when he decided to return to his homeland) (Società Dante Alighieri, 1909). In 1910, the Minister of Grace, Justice and Religion, Scjaiola, presented a new, organic proposal for reforming citizenship law. The historical and social context seemed favourable to introducing significant innovations in relation to the old law. Many people, however, including the Italian expatriates and their organisations, were disappointed by the measures adopted.

\section{The New Law of Citizenship (Law no. 555/1912)}

The law on citizenship was reformed in 1912.Before the new law was approved, two others had been passed by Italian Parliament regarding the same issue: Law no. 23/1901 and Law no. 217/1906.

What were the innovations introduced by these two laws? Law no. 23/1901 partially reformed the Civil Code from two perspectives: it suspended the obligation to perform military service if the Italian citizen resided abroad and had left Italy before turning 16. The only exceptions were calls to arms due to a risk of war (Chapter 4, Disposizioni speciali sul servizio militare e sulla cittadinanza). The second modification concerned the abolition of Article 11(3) of the Civil Code. In this case, Italian citizens resident abroad could now work for the state in which they lived without losing their original nationality.

Law no. 217/1906, presented by Sonnino (CD, 1905), tackled just one issue: the naturalisation of foreign citizens who resided in Italy and requested Italian citizenship. Once more, the historical context was decisive, since the strictness of Italian law had allowed fewer than 20 naturalisations in 44 years. Italy was therefore losing its citizens who expatriated and was unable to acquire foreign residents living in its territory. Because of this paradoxical situation, Sonnino put forward this draft law, which consisted of only three articles, all about the acquisition of Italian citizenship. In order to be naturalised, the following conditions had to be met: a favourable opinion from the Council of State; six years of residence in Italian territory or four years of service to Italian State; to have married an Italian woman or to have made special services to Italian 
State. The only limitation was that the naturalised citizen could not be elected to either of the two Italian chambers for six years following acquisition of the new nationality.

These partial modifications did not significantly alter the philosophy with which the Italian law on citizenship had been inserted into the Civil Code. What about the new organic law on citizenship, which was approved in 1912?

The Scialoja Report submitted to the Italian Senate explained the Government's objectives regarding this issue: "1) to attenuate the international conflicts of law (..);2) to ensure that the right determined by citizenship responds, normally, to the status quo determined by the current subjection of the individual to the state in which he resides $(\ldots) ; 3)$ to treat family relationships with the utmost care $(. .) ; 4$.$) to allow every defini-$ tive change in the state of citizenship to be voluntarily made by the individual" (SR, 1910: p. 4). Scialoja pointed out that the reform of Italian citizenship was necessary due to an important phenomenon that was almost unknown when the Civil Code had been approved in 1865: migration. In addition, systematisation was needed because of the fragmentation of legislation and the confusion it brought about caused by the many laws that were involved in citizenship. A new philosophy of law was expressed by Scialoja: if the Civil Code was designed for a nation still under construction, and consequently with an "autarchic" vision in mind, it was now necessary to open new perspectives, especially towards international law. In fact, Italy was trying to sign agreements with the states that had numerous Italian migrants, but it was proving to be a very difficult exercise. The new Italian law on citizenship had to consider this new factor, adapting its law to the new international conditions. This would have been absolutely unthinkable only 50 years before. Nevertheless, those who were born abroad to Italian parents and continued to reside abroad would have lost immediately their Italian citizenship, which would have been recovered once they reached the age of majority, provided that they resided in Italy.

In any case, there were many significant difficulties, since most Italian MPs and senators were anchored to Cicero's formula Nemo duarum civitatum civis esse potest, which excluded a priori the explicit adoption of dual nationality. Scialoja tried to mediate these ideological positions with actual needs to give effective answers to the claims made by the Italian expatriate associations, which did not want expatriates to lose their original nationality.

Government instability and growing difficulties in finding an agreement on the different points of the law caused a delay in the discussion of the Scialoja draft law. One-and-a-half years later, the debate on the citizenship law at the Senate took place. The political scenario had changed: the new minister, Finocchiaro Aprile, had ideas that were partially different from Scialoja's views, as did the law rapporteur, Senator Polacco. The new draft law intended to maintain Italian citizenship for Italian citizens and their descendants living abroad, including in those cases that the Scialoja draft provided for the loss of this condition.

The gap between the traditional doctrine-which fitted well with the positions of the moderates and nationalists and was prevalent in Italian Parliament-and the social 
reality at the time was notable in the speech made by the MP Fusinato at the Camera dei Deputati. Speaking on behalf of the Italian expatriates, he criticised the shortsightedness shown by the Government and the majority of his colleagues. He pointed out that the institution of dual nationality, which had been rejected, should be thought of as "an unhappy expression (...) but a trend that is right, in my opinion" (CD, 1912). His concerns for the Italian expatriates were shared by Cabrini, a prominent exponent of the Socialist Party. In any case, the conservative and nationalist majority at the Parliament frustrated every attempt to change the original text.

The new Italian law on citizenship (Law no. 555) was approved in 1912. Its key principles can be summarised as follows: the criteria for acquiring Italian citizenship were similar to those in the Civil Code, with some modifications. First of all, Ius sanguinis and the patrilineal system were maintained. According to Article 1, an individual was a citizen by birth if the father was Italian; if the mother was Italian and the father was unknown or did not have Italian citizenship or any other citizenship; if the father could not transmit his citizenship to his children; if the individual was born in Italian territory and both the parents were unknown or did not have Italian citizenship or citizenship of another state or if the parents did not transmit their citizenship to their children. Citizenship could be acquired by foreigners born in Italy or those whose parents had resided there for the preceding 10 years, if they had served the Italian army or had accepted a public job; if they were resident in Italy at the time of their $21^{\text {st }}$ birthday and declared their desire to obtain Italian nationality before their $22^{\text {nd }}$ birthday; if they had resided in Italian territory for at least 10 years and did not declare that they wanted to conserve their foreign citizenship before their $21^{\text {st }}$ birthday. Italian citizenship could be obtained by Royal Decree by any foreigner that had: provided services to the Italian state for at least three years; resided in Italy for the last five years; resided in Italy for the last 2 years and rendered special services to Italy or married an Italian woman; resided in Italy for the last 6 months, for those who could choose Italian citizenship but had failed to do so. A new citizen could enjoy all rights, including political rights.

The other pillar of the new law was the impossibility of having two nationalities. Italian citizenship was therefore lost by those who voluntarily acquired a different nationality and moved their residence abroad. It was also lost by those who did not voluntarily acquire a foreign nationality but declared that they renounced their Italian citizenship and moved their residence abroad. Finally, those who worked for a foreign state or performed military service for a foreign state after being notified by the Italian authorities to cease this activity would also lose their citizenship.

Women continued to be subjugated to their husbands. In fact, since the family had to remain united, the woman always had to follow her husband's nationality, even if he changed it to become a foreigner. An Italian woman who got married to a foreigner would lose her original nationality. Only in the case of the legal separation of spouses without children could the wife choose to keep her original citizenship (Article 11). If the father recognised his child after the mother, the child would acquire his father's citizenship; if their child was already an adult, he/she could-within a year-chose 
his/her mother's nationality (Article 2).

What conclusion is it possible to make in relation to this new law? The debate that occurred immediately after it was passed revealed a clear characteristic: ideologically, the prevalence of nationalism had emerged, to the detriment of a more objective analysis of social reality. Migration and the events organised by the Italian expatriate associations had not been enough to substantially change or alter the logic of uniqueness of citizenship; the first struggles of women and their incipient movements had not been regarded as important enough to dictate a modification to the patrilineal system, despite the rare exceptions that Law no. 555 introduced, particularly related to the legal separation of spouses without children. It is worth noting that the Italian legal system did not have a law on legal separation or divorce at the time, so this case partially contradicts Italian law. Once again, the principle of the family unit prevailed over wives' free choice to determine their citizenship. What Law no. 555 tried to attenuate were cases of statelessness, giving Italian citizenship to all people who were born in Italy to unknown parents (which meant applying Ius soli in exceptional cases). Also, when an Italian citizen decided to reside abroad or work for a foreign state, the new law corrected the provisions of the Civil Code, according to which the loss of original citizenship was immediate. Now, the Italian state had to warn its citizens, drawing their attention in order to prevent them from losing their original nationality. In addition, the new law abolished the distinction between greater (or full) and lesser citizenship, and made the rights of natural and naturalised citizens the same, especially in terms of political rights. Finally, there was a wide gap between the ideology and doctrine used by the Italian Parliament: the social trends and movements that were running through Italian society and politics at the time had no influence on the text of the law. An attenuation of these key principles could be seen in the sense that Italian law on citizenship now expressed a more open trend towards keeping its citizens, as in the case of loss of nationality (Article 8). According to this article, only Italian citizens who had voluntarily requested foreign nationality and who lived and worked abroad would lose their original citizenship. Automatic mechanisms of loss of citizenship were overcome by the new law, revising the provisions of the Civil Code. It can be considered one of the actual (and very timid) responses by the Italian legal system to the phenomenon of the massive loss of Italian nationality by many migrants.

One of the biggest critics of the new law was Buzzati. As an advocate of the institution of dual citizenship, he demonstrated the contradictions of Law no. 555 on the matter. The law, in spite of its firm principle of uniqueness of citizenship, caused several cases of dual nationality. Buzzati remembered the irreconcilable conflict between migration and the adoption of Ius sanguinis as the main regulatory principle of nationality. In his opinion, Italian migrants had to be recognised as citizens of their host state but at the same time they had to maintain a link with Italy not only through a spiritual bond but also through the only possible legal instrument, Italian citizenship (Buzzati, 1916). He showed that dual citizenship, which Italian legislators refused to adopt explicitly, existed de facto in Law no. 555/1912. Among the different circumstances, he 
remembered Article 2(2), which originated cases of dual nationality for minors if recognition of an Italian father occurred after recognition of a foreign mother. The minor did not lose the mother's citizenship but acquired the father's nationality and would have dual citizenship. However, the fulcrum of the debate on this subject was Article 8, which was related to the loss of citizenship. Buzzati considered the new provision according to which an Italian citizen working for a foreign state and resident abroad would not automatically lose Italian citizenship. In his opinion, this reform of Article 11 of the Civil Code protected against cases of statelessness and created many individuals with dual nationality. In fact, according to Article 8 of Law no. 555/1912, people would have to voluntarily acquire another nationality to lose their Italian citizenship. This meant implicitly allowing dual nationality, with Buzzati's complacency (Idem). The same position was expressed by other commentators, including De Dominicis (De Dominicis, 1916).

On the other side, conservative commentators defended the new law. Gemma, for instance, rejected all the arguments used to justify the adoption of the institution of dual citizenship in the Italian legal system. First of all, Italian migrants had to reject the acquisition of a foreign citizenship, since their participation in public life of the host state was not as important; secondly, he considered the infringement of the principle of Ius sanguinis to be heresy, so the law could not subjugate its philosophy to social needs but rather to contingent needs (Gemma, 1923).

Degni also defended the principle of adopting Ius sanguinis and the uniqueness of citizenship but admitted that cases of dual citizenship could arise involuntarily (Degni, 1921).

The other great debate after the approval of Law no. 555/1912 concerned the condition of wives in relation to their husbands.

In this case, the positions were more connected than for the principle of uniqueness of nationality. Conservative commentators, like Gemma and Degni, also raised some doubts. In fact, while it is true that the main principle had to be the family unit, there was some reserve about the excessively passive role of wives in relation to their husbands.

The debate was essentially focused on a change to the husband's citizenship. Degni, for example, stressed that it was impossible to derogate the "supreme necessity of unity in the constitution of a family", including in the legal separation of spouses, since this condition could be reversed for a return to marriage (Degni, 1921: pp. 161-162). This meant that wives had to assume their husbands' nationality in every case. The problem arose when a foreign husband decided to change his nationality. Based on the principle of family unity, his wife had to follow his nationality; Degni admitted, however, that there was an exception. He spoke of an "impairment of the wife's personality", theorising that the wife could avoid following her husband's nationality once he moved abroad and that she could maintain her original nationality but it would violate the key principle of family unity (Degni, 1921: p. 162). As an alternative to this radical position, Degni introduced the possibility of the wife following her husband but left her the chance to 
conserve her original citizenship. In this case too it is not difficult to see a potentially major conflict with the key principle of uniqueness of citizenship: in fact, while conservative positions like the one expressed by Degni made a strict connection between nationality and citizenship, in this case the tie would be broken. Furthermore, the wife could acquire her husband's nationality but if she declared that she wished maintain her original nationality, she would become automatically a citizen with dual nationality.

The same difficulties can be seen when analysing Gemma's position. He also thought it was necessary to soften the principle of family unity by including the principle of the wife's wishes. He concluded as follows: "the legislator did not want to state (because it would be excessive) that she too had to coercively follow all of her husband's changes of nationality; he just wanted to state the principle that women cannot, through an act of her own initiative, break the marital family unit, which could cause very serious conflicts in some situations" (Gemma, 1923: pp. 84-85). Gemma concluded by pointing out that it was necessary to choose the lesser of two evils, i.e. the wife would lose Italian citizenship if she decided to marry a foreigner rather than breaking family unity.

A last, relevant subject concerned the political rights of naturalised Italians. As explained above, Law no. 555/1912 abolished the differentiation between "greater" and "lesser" nationality. Only 17 days after Law no. 555 was approved, a new electoral law was passed. Law no. 665/1912, Sulla riforma dellalegge elettorale politica, contained many articles but just two were strictly related to citizenship: Article1 stated that electors had to enjoy the civil and political rights of the Kingdom. Individuals who had obtained Italian nationality through a Royal Decree now became electors too. The same was true for elections for the lower chamber (Camera dei Deputati). However, in these two cases, Law no. 665 referred to the citizenship law of 1906 and not to the law of 1912, which caused serious legal interpretation issues. In fact, the two laws differed due to the acquisition of electoral rights by naturalised Italians. Careful commentators stressed this problem and pointed out that Law no. 665 mentioned an abrogated rule and not the one in force at the time (Diena, 1912). This meant that naturalised citizens were prohibited from being elected to the lower chamber and had stricter conditions for being electors. Diena proposed the approval of an ad hoc law to correct the mistake, which would have seriously penalised a group of people who should have been considered to be fully Italian.

A definitive way of interpreting this dilemma was given by Esperson. As explained by Diena, the problem was circumscribed to the electoral rights of naturalised people. In this case, Esperson assumed that the Italian Parliament (namely, the Senate) voluntarily approved the new electoral law knowing that a new citizenship law had already been passed. In fact, the Camera dei Deputati approved the draft electoral law in May 1912. The Italian citizenship law was, at the time, Law no. 217/1906, so the only possible reference should have been to this law. The Senate began its discussion of the new electoral law on 24 June 1912 and it concluded five days later, i.e. 16 days after the approval of Law no. 555. The Senate had the time to change this obsolete reference and introduce the correct one. But it decided not to do so. Why not? According to Esperson, it was 
because of pressure exerted by the Prime Minister, Giolitti, on the Senate. He wanted the electoral law to be passed quickly, and thought that the above-mentioned mistake should be overcome ipso iure because Law no. 217/1906 had been replaced by Law no. 555/1912 (Esperson, 1913). Finally, the reference to the old law was not completely pointless. The Royal Decree of 2 August 1912 stated that (Article 10) requests for the acquisition of Italian citizenship presented before 1 July 1912 had to follow the process and provisions of the laws approved before no. 555/1912. Law no. 217/1906 therefore ended when it was replaced by Law no. 555, even though it was limited to requests for naturalisation submitted before 1 July 1912 (RD 949/1912).

The approval of the new citizenship law in 1912 must be considered an important step in the construction of the Italian concept of nationality. In fact, a continuation can be clearly seen from the Civil Code of 1865 to the new Law no. 555. This continuity can be explained through the proximity of the Italian legislators' political tendencies in the two periods considered here. A conservative point of view in relation to social, economic and cultural phenomena was common in the Italian ruling classes. Moreover, in the latter period, waves of nationalism and colonialism (the colonisation of Libya began in 1911), which were spreading in Italy, together with aggressive political movements, were strengthening the ideological bases of the traditional principles of nationality. Fascism merged all of them and removed any possibility of democratic debate and discussion, including discussion of Italian citizenship.

\section{Italian Citizenship between the First World War and the Peace Treaties: A Brief Overview (1914-1920)}

After the approval of Law no. 555/1912, the gap between the political class and some significant social movements became very wide. As shown above, the main issues had not been solved by the Italian Parliament.

With the First World War and its related treaties, the focus centred on issues closely connected to the treatment of "new" Italians in the annexed territories, such as Alto Adige, and the protection of Italian minorities, especially those living in Dalmatia, a region of the new Kingdom of Serbs, Croats and Slovenes.

There were two issues during the First World War that dealt with the question of nationality and caught the attention of Italian legislators. Firstly, there was the issue of "Italiani non regnicoli" ("Italians not belonging to the Kingdom", henceforth INR). This topic had been relatively important before the political unification of the peninsula. The Savoy state had approved its electoral law (Royal Edict no. 680/1848), which gave INR the right to vote because they had "lesser" nationality. This feature was maintained in successive electoral laws and the Civil Code of 1865 rejected the differentiation between Italians and INR. The electoral law of 22/11/1908 made the same decision, with the only limitation that INR were not eligible for the position of mayor. Although many special INR rights had been recognised, they could not be compared to those enjoyed by Italian citizens (BUFARDECI, 1923). This conclusion caused a certain concern among Italian politicians, who had a tendency to absorb INR into the wider Italian 
family, for comprehensible reasons related to the war.

The second issue faced throughout the First World War consisted of a series of provisions designed to impede Italian citizens from doing business and trading with citizens of belligerent states, in particular the Austro-Hungarian Empire. An apparently secondary issue was actually particularly important. Lieutenant Decree no. 920/1915 (Prohibition, in the Kingdom, of real estate sales and other operations with subjects of the Austro-Hungarian Empire during the war) raised-maybe involuntarily-a very important question: for the first time, Italian law proposed an equal footing, in terms of nationality, for individuals and commercial entities. In addition, it distinguished between "nationality" and "citizenship". The case that caused a heated debate was rooted in the request by two companies based in Trieste (General Insurance and the Adriatic Union of Security) to be certified as Italian by the Government of Rome. Trieste was, at that time, part of the Austro-Hungarian Empire. The issue that this request raised was whether a company based in a foreign territory could be considered Italian, in terms of nationality, as Buzzati pointed out (Buzzati, 1916). The first point was whether or not it was possible to talk about nationality for a company; it seemed that it was, based on Article 230 of the Italian Commercial Code and an international debate had also concluded that it was possible (Segrè, 1918). The second issue was yet more problematic. In this case, Buzzati expressed an opinion that was clearly influenced by the climate of war at the time. In fact, he stressed that a series of reasons made it possible to conclude that the two companies should be considered as Italian. Firstly, because of the permanent location of their head offices in Trieste, a town which symbolised an "Italian Sea", the Adriatic; secondly, their articles of association were written in Italian; thirdly, although they were dominated by Austria, but this did not mean that they wanted to be part of it. Therefore, when Italian Government granted Italian citizenship to these two companies, the distinction between nationality and citizenship became effective for the first time in Italian law. Confirmation came in the form of another Lieutenant Decree, no. 1829/1918, in which Italian legislators excluded-also for the first time-the prohibition of all subjects or entities that had Austrian nationality but Italian citizenship, which had been established in the preceding Decree no. 920/1915.

As a consequence of the end of the war, several treaties were signed between the different states. The two most important treaties for Italy were the Treaty of SaintGermain-en-Laye, signed on 10/09/1919 by almost 20 states, among which Italy and Austria, and the Treaty of Rapallo, signed by Italy and the Kingdom of Serbs, Croats and Slovenes on 12/11/1920.

The Treaty of St. Germain dealt with the question of citizenship in two sections, section V, Protection des Minorités, under the supervision of the League of Nations, and section VI, Clauses concernants la nationalité. For Italy, these clauses meant that Alto Adige passed to the peninsula and that its inhabitants became Italians, losing their Austrian citizenship. Nonetheless, not all these people automatically acquired Italian citizenship: the rule could not be applied to those who were not born in those territories or those who had acquired Italian citizenship before 24 May 1915 (the date on 
which Italy entered the conflict) or those who did it "seulement en raison de leur position officielle". Nevertheless, it was possible for them and those who had joined the Italian army during the war to request Italian citizenship. In every case, the choice of one of the two citizenships involved moving residence-within a year-to the relevant country. Wives always had to follow their husbands' decisions.

The Treaty of Rapallo was characterised by the strategy of friendship promoted by Giolitti in Italian relations with the Kingdom of Serbs, Croats and Slovenes. Zara became Italian, unlike Dalmatia and Fiume (which had independent status); a few groups of Adriatic isles became Italian, while all the others joined the new Kingdom of Serbs, Croats and Slovenes. Article 7 of the treaty was devoted to citizenship: it stated that Italian citizens and companies in Dalmatia had to be protected and should maintain their business and activities. It also declared that members of the Italian minority living in the territory that now belonged to the new Kingdom and had previously belonged to the Austro-Hungarian Empire could opt for Italian citizenship. Finally, the new Kingdom recognised Italian degrees, while Treaty introduced a new agreement for recognition the other way round.

The Italian Parliament approved the two treaties but the debate introduced a new atmosphere. A new political party, the Nationalists, began to explore the question of nationality as its key issue. Colonna di Cesarò, a nobleman, pointed out that Dalmatia, which had been left to the Kingdom of Serbs, Croats and Slovenes, was "one of the purest and most glorious branches of our people" and that it had now been left "without defences or guarantees"; his colleague Benelli spoke of "the fear of barbarian slavery" (CD, 1920).

Times were changing and the ideology of an extreme nationalism, together with the idea of the "mutilated victory" of the First World War, was rapidly spreading throughout Italian institutions. When the new spirit of nationalism encountered the violence of fascism, a new warlord was appointed: Benito Mussolini.

\section{Citizenship Law during Fascism (1922-1943)}

When fascism came into power, following a coup d'état (the March on Rome, 1922), an enormous ideological apparatus had been designed to give an effective response to the popular calls for greater dignity for Italy in the international landscape.

In fascist ideology, the theme of nation and nationality was one of the most important. In the first fascist period, some intellectuals formulated the bases for defining a clear concept of "Italianness". Grandi, for instance, one of the most prominent fascist personalities, wrote that interest should be restricted to the nation (Grandi, 1922), while the philosopher Gentile wrote that war was the only occasion "to cement this nation in blood, as it had been formed more by chance than thanks to the values of its children" (Gentile, 1925). Consequently, the idea that fascism promoted regarding citizenship was quantitative: increasing the number of Italian citizens meant forcing the rules that were in force at the time. However, there was also a qualitative aspect promoted by fascism: the identification of Italian citizenship with fascism. For this reason, those who 
were not fascist could not be Italian (De Felice, 1981: pp. 292-293).

With these ideological convictions, some could think that the issue of citizenship was foremost in the concerns of fascist politics. In truth, the regime led by Mussolini never passed an organic law on citizenship. The only attempt to do so was carried out by the Minister of Justice, Rocco, in 1930, but the Parliament never approved his draft law.

A brief summary of the provisions fascism approved regarding citizenship follows:

1) In order to increase the number of Italian citizens, fascism passed the Royal Decree of 29/01/1922 ( $R D$ 43/1922). It stated that for citizens belonging to the territories annexed by the war, the declaration to acquire Italian citizenship would be delayed by approximately one year from the original date (13/07/1921). The Royal Decree of $18 / 11 / 1922$ simplified the procedures for obtaining Italian citizenship (the opinion of the Council of State was no longer mandatory, as established by Law no. 555/1912) for those who had Italian parents, had lost their original citizenship and wanted to reacquire it, even if they were not resident in Italy (RD 1655/1922). This category of new citizens could not serve in the Italian army or vote, and therefore the institution of "lesser citizenship" returned. Some observed that the new demands related to the war had forced the Government to reintroduce this differentiation, which was not flawless from a legal point of view (Giannini, 1935). Royal Decree no. 1997/1934 replaced Article 4 of Law no. 555/1912, in that the opinion of the Council of State was no longer mandatory to grant Italian citizenship. It also reduced the term for obtaining Italian citizenship for foreigners residing in Italian territory who had provided special services to Italian state or married an Italian woman from 3 years to 2 years. Immediately, a large portion of legal doctrine aligned its positions to the new fascist philosophy: the fact that the Council of State had to give an opinion contrasted with "the concept of the functions of the Government according to the political doctrine of fascism" (Lampis, 1935: p. 310). Government discretion therefore began to constitute the main criterion for granting Italian citizenship, which was a tendency that had been clearly expressed by the draft law submitted by Rocco in 1930. Here, the pillars for determining Italian citizenship remained anchored to the tradition of local law: the adoption of Ius sanguinis, the uniqueness of Italian citizenship, the emphasis on the patrilineal system (even an individual recognised by his father as an adult had to follow his citizenship and would lose his mother's citizenship), easing the process of a foreign resident acquiring Italian citizenship, impediments to renouncing Italian citizenship-which made the explicit desire of the applicant, formal authorisation from the Government and the effective choice to reside abroad compulsory conditions-the maintenance of Italian citizenship for minors whose fathers changed their citizenship. As the minister Rocco eagerly explained, the principle that guided the proposal was the "defence of Italian citizenship", in which the Government played a prominent role in determining the acquisition and, particularly, the loss thereof (SR, 1930). However, the most explanatory words came from a legal expert who had a clear memory of the most important debates on citizenship inside and outside the Parliament. Baccelli, the law rapporteur, emphasised the continuity that the principles of the new draft law represented for 
the clauses of Law no. 555/1912 and pointed out the reasons why the legislators were putting forward some significant modifications. The modifications can be justified by the historical period in which the draft law had been presented: war and international competition between states had stimulated the importance of demographics in determining citizenship law. He concluded as follows: "power is strength and strength is, to a great extent, in numbers" (SR, 1933). In relation to dual citizenship, Baccelli claimed that the interests of the nation had to prevail over those of the individual, so that it was impossible to speak of dual citizenship, but rather of citizenship "contended between two national units or states" (Idem). These principles, as mentioned above, were not introduced in an organic law, and only the small modifications mentioned above were introduced by fascism in relation to citizenship law.

2) In order to limit the rights of citizenship for some special categories of citizens, fascism approved the following laws: at the start of its political trajectory, Law no. 108/1926 and Royal Decree no. 19/1926. Both these laws dealt with limitations to citizenship rights for political enemies, leaving broad freedom of decision for the Government. Italian citizenship could be revoked if an Italian citizen committed an act abroad that dishonoured the good name of the country, even if it was not a crime. Italian citizenship could be revoked also for citizens who had acquired it if their political behaviour was "unworthy". At the end of its political journey, fascism adopted laws that were openly against the Jews. Influenced by Hitler's Germany, Mussolini imposed, through the Royal Decree no. 1728/1938, the introduction of the concept of the "Aryan race", which was completely alien to Italian legal tradition. A citizen of "Jewish race" could not marry any Italian citizen of another race or (Article 2) any foreign citizen unless the Minister of Internal Affairs gave his authorisation. Jewish Italian citizens could not be appointed guardians of minors or disabled people of other races, nor serve in the national army. In addition, they could not manage companies that dealt with issues related to national security, own land worth more than 5000 lire or buildings with a taxable value of more than 20,000 lire. If the children of Jewish parents joined another religion, the state could remove their parental authority. Jewish Italian citizens could not ever serve the state. While this was the most controversial legal measure adopted by fascism, another provision emerged following pressure from Hitler. In 1939, Hitler and Mussolini signed an agreement on the citizenship of the German-speaking people living in Alto Adige, a region that had been annexed to Italy after the end of the First World War. The agreement stated that the Italian Government would facilitate the choice of German citizenship for those people who demonstrated this desire. This measure went against all the propagandistic ideas that Mussolini had spread about increasing the number of Italian citizens.

3) Finally, the other important contribution of fascism to citizenship law was the introduction of different levels of citizenship according to colonial law. Before fascism, three Royal Decrees had been issued to regulate the relationships between citizens and subjects (RD no. 315/1913, Sulla sudditanza; RD no. 931/1919, Sulla cittadinanza e il governo della Tripolitania); RD no. 2401/1919 (Sulla cittadinanza e il governo della 
Cirenaica). Fascism approved laws to organise all these aspects related to citizenship and the rights of the new Italian colonised people in a more organic way. Law no. 1013/ 1927, Legge organica per P amministrazione della Tripolitania e della Cirenaica, defined Libyan citizenship as citizenship transmitted from a Libyan father (or mother if the father was unknown), who was born in Libya, regardless of place of residence, on the condition that the person was not an Italian citizen and did not have foreign citizenship. Libyan Italian citizens could acquire Italian citizenship once they reached the age of 21, provided that they had not committed polygamy, had no convictions for political crimes, had attended at least the $3^{\text {rd }}$ year of Italian school, and were loyal to Italy. RD no. 1146/1932 forced Italian Libyan citizens aged 16 to 60 to serve in the national army if it was mobilised for war. Law no. 999/1933 established the same provisions for Eritrean and Somali subjects but without the many prerogatives reserved for Italian Libyan citizens (Monaco, 1937). In coherence with the law for the defence of Aryan race, RD no. 70/1939 impeded marriage between Italian citizens and Italian subjects, with a sentence of up to 5 years' imprisonment for Italians who disrespected this law. A special Libyan Italian citizenship was established for Muslim subjects.

At the end of fascism, the types of citizenship were: a) Mainland citizenship, but with "lesser" citizenship for foreign residents who had acquired Italian citizenship and the political and racial limitations described above for some special categories of citizens; b) Libyan Italian citizens; c) Libyan Italian Muslim citizens; d) Italian subjects, reserved for the colonised people of Eritrea and Somalia.

This inextricable jumble of different types of citizenship demonstrates the great confusion with which fascism dealt with such an important matter. In fact, despite the ideological declarations, no organic law on citizenship was approved by Mussolini's regime. Furthermore, the issue was approached in contingent situations, which had the immediate consequence of completely distorting the most elementary principles of public law, at least the principles of Italian legal tradition. It was the war that first guided the approval of new laws, emphasising a demographic philosophy, then political domestic battles against opponents that had to be silenced, then management of the colonial situation, and later the urgent request received from Germany to establish a new concept of "Aryan race" and, hence, to draw up special measures for inferior civilisations, such as the Jewish and Muslim ones. Finally, another demand came from Hitler to favour the loss of Italian citizenship for German minorities living in Italian territory, belying all the nationalist rhetoric that characterised fascist discourse (rather than legal measures) on citizenship.

This is the scenario that the new Italian constituents found in the aftermath of the fall of fascism. Their task was very difficult: they had to re-establish a legal rationale and coherence in the citizenship law. A new era was beginning, so the fascist provisions had to be considered completely null. New work had to begin.

\section{Conclusion}

This article aimed to show how Italian citizenship law changed during the monarchic 
era, a long and intense period in the country's history as in all of the other European states. Using a mixed research methodology, the article attempted to connect the transformations in Italian citizenship from a legal point of view with what was happening in the Italian political and social scenario. Finally, a relatively exhaustive framework emerged.

The key historical subdivision into two sub-periods, before and after the advent of fascism, showed that, in this specific case, it is impossible to observe correspondence in the development of Italian citizenship, at least for the most important aspects of the issue. In fact, the base formed by the principles established in the Italian Civil Code of 1865, and confirmed-with a few innovations-by Law no. 555/1912 and other less important provisions, presents a continuation of fascism ideology and decisions.

Throughout the liberal era, especially from the end of the $19^{\text {th }}$ century, social movements began to pressure the Italian Government and Parliament to change citizenship law, bearing in mind the cases of women and expatriate associations. This was a situation in which women had to renounce their nationality to follow their husbands' in the name of preserving family unity. It was less acceptable still that Italian expatriates had to lose their nationality when they acquired the nationality of the state in which they were living and working.

Before this situation, the Italian legislators were indifferent and considered fidelity to the original principles established in Civil Code of 1865 to be more important than rapid social and cultural transformations. The gap between the political and legal elitewhich were the same, to a large extent-and Italian society remained constant throughout the liberal era. The history of citizenship represents just one of the many examples that confirm it.

With the First World War, this gap increased: the political problems of a "mutilated victory" fitted with serious social troubles that the liberal elite that had managed Italy since its independence was unable to face. When fascism violently took over leadership of the country, its ideology was extremely nationalist and intolerant of its political enemies.

The first laws on citizenship in the fascist era aimed to limit some fundamental rights for special categories of citizens, namely political dissidents. However, the question of citizenship never appeared to be prominent in Mussolini's agenda. Or rather, Mussolini tried to establish a concept of citizenship based on the strength of numbers, so, in his opinion, it was a contradiction to lose millions of Italians who lived abroad simply to maintain erudite fidelity to the doctrine. In addition to the definition of the new Italian as fascist, it was necessary to recover compatriots living abroad and dispute their citizenship with other states. Without succumbing to the idea of introducing the principle of dual citizenship into Italian law, he wished to accentuate the criterion of Ius sanguinis, straining the most elementary rules of Italian public law.

This was the path that the minister Rocco tried to follow in 1930 with his draft law. Nevertheless, the only law coherent with the fascist doctrine of citizenship was passed in 1934 and it was certainly not an organic law. 
After the second half of the 1930s, fascism began to deal with the question of citizenship erratically and on the basis of contingency. The colonial experience in the Horn of Africa, together with the military alliance with Hitler, caused two different and contradictory scenarios: the already complicated citizenship law of the ancient colonies (Tripolitania and Cyrenaica, the two regional subdivisions of Italian Libya) became even more abstruse for the racist provisions that Mussolini adopted against Muslim people and the "new colonisers" of the Horn of Africa; he issued special rules for Jewish Italian people, taking away many of their fundamental human rights. The agreement signed with Hitler in 1939 forced him to make it easier for individuals in the German minority in Italy to acquire German nationality, renouncing their Italian nationality, which was clearly in conflict with his demographic convictions in relation to citizenship law.

Similar difficulties were encountered by the Italian Republic's legislators when defining the new citizenship law after the end of the Second World War. It is enough to remember that fidelity to the principle of Ius sanguinis and the uniqueness of nationality were the two key pillars of new Italian citizenship for many years, in part even today.

\section{References}

Bollati, G. (1983). L'italiano. Torino: Einaudi.

Borsari, L. (1871). Commentario del Codice civile italiano, Vol I. Torino-Roma-Napoli: UTET.

Bufardeci, C. (1923). Gl'italiani non regnicoli nel nostro diritto positivo. Rivista di Diritto Pubblico, 1, 602-644.

Bussotti, L. (2002). La cittadinanza degli italiani. Milano: Angeli.

Buzzati, G. C. (1916a). Note sulla cittadinanza. Rivista di Diritto Civile, a. VIII. Milano: Società Editrice Libraria.

Buzzati, G. C. (1916b). La nazionalità italiana di enti morali stranieri. Milano: Vallardi.

Calcaterra, V. (1873). Genesi e sviluppo del Codice Civile del Regno d'Italia, Vol. I. Salerno: Premiato Stabilimento Tipografico Migliaccio.

Costa, P. (2005). Cittadinanza. Roma-Bari: Laterza.

D’Amelia, M. (2006). Donne alle Urne. La conquista del voto. Documenti 1864-1946. Roma: Biblink.

De Dominicis, F. (1916). Commento alla legge sulla cittadinanza italiana del 13 giugno 1912. Torino: UTET.

De Felice, R. (1981). Mussolini il duce. Lo Stato totalitario 1936-1940. Torino: Einaudi.

Degni, F. (1921). Della cittadinanza. Torino: UTET.

Diena, G. (1912). La nuova legge elettorale politica e gli stranieri naturalizzati italiani. Rivista di Diritto Pubblico, a. IV, Parte Prima, 552-561. Milano: Società Editrice Libraria.

Donati, S.(2013). A Political History of National Citizenship and Identity in Italy, 1861-1950. Stanford, CA: Stanford University Press.

Esperson, P. (1883). Condizione giuridica dello straniero secondo le legislazioni e la giurisprudenza italiana ed estera, i trattati fra l'Italia e lealtre nazioni. Torino: Fratelli Bocca.

Esperson, P. (1913). La nuova legge elettorale politica e gli stranieri naturalizzati italiani. Giurisprudenza Italiana, Quinta Serie, a.LXV. Torino: UTET. 
Gemma, S. (1923). La legge 13 giugno 1912, sulla cittadinanza. Padova: CEDAM.

Gentile, G. (1925). Origini e dottrina del Fascismo. Roma: Libreria del Littorio.

Giannini, A. (a cura di) (1935). La cittadinanza italiana. Roma: Anonima Romana Editoriale.

Gianzana, S. (1888). Codice civile, Vol. II, Discussioni, n. 185. Torino: UTET.

Gioberti, V. (1846). Del primato morale e civile degli italiani. Capolago: Tipografia Elvetica.

Grandi, D. (1922). Le origini e la missione del fascismo. Bologna: Cappelli.

Lampis, G. (1935). Le nuove norme sulla concessione della cittadinanza italiana. Rivista di Diritto Pubblico, a. XXVII.

Mancini, P. S. (1851). Della nazionalità come fondamento del diritto delle genti. Torino. [New Edition: Mancini, P. S. (2000). Della nazionalità come fondamento del diritto delle genti. Torino: Giappichelli.]

Mazzini, G. (1860). Dei doveri dell'uomo. [New Edition: Mazzini, G. (2010). I doveridell'uomo. Milano: Rizzoli.]

Migliacci, D. (2011). Storia e Costituzione. Milano: Angeli.

Monaco, R. (1937). Caratteri della sudditanza dell'Africa Orientale Italiana. Rivista di Diritto Pubblico, 1, 239-247.

Riall, L. (1994). The Italian Risorgimento: State, Society and Nation Unification. London: Routledge. http://dx.doi.org/10.4324/9780203412343

Ricci, A. (1891). Il principio dell'unità di famiglia nell'acquisto e nella perdita della cittadinanza. Rivista Italiana per le Scienze Giuridiche, 13, fasc. I.

Romanelli, R. (1979). L'Italia liberale (1861-1900). Bologna: Il Mulino.

Rossi-Doria, A. (1996). Diventare cittadine. Il voto alle donne in Italia. Firenze: Giunti.

Salvatorelli, L. (1975). Il pensiero politico italiano dal 1700 al 1870. Torino: Einaudi.

Sechi, O. (1897-1902). Cittadinanza.Il Digesto italiano. Enciclopedia metodica e alfabetica di Legislazione, Dottrina e Giurisprudenza, Vol. VII, Parte Seconda. Directed by L. Lucchini. Torino: UTET.

Segrè, G. (1918). La nazionalità delle società secondo i giuristi francesi \& La nazionalità delle società e la giurisprudenza inglese. Rivista del Diritto Commerciale, 2, 458-469.

Institutional Documents

CD (Camera dei Deputati) (1865). Relazione della Commissione della Camera Elettiva sul progetto di legge per l'unificazione legislativa, presentato dal Ministro Guardasigilli (VACCA) nella tornata del 24 novembre 1864 (Tornata dell'8 febbraio 1865). Codice Civile, II, Discussioni. Torino: UTET.

CD (Camera dei Deputati) (1905). Proposta di legge d'iniziativa del Deputato SIDNEY SONNINO svolta e presa in considerazione nella tornata del 24 maggio 1905, "Norme per la concessione della cittadinanza", Legislazione XXI, Sessione 1902-904. Documenti-Disegni di legge e Relazioni, n. 79, pp. 1-4, n. 179-A (6 Giugno 1905), 1-6, n. 179-B, 4 Maggio 1906, 1-2, n. 179-C, 9 Maggio 1906, 1-3, Relatore Vincenzo Riccio.

CD (Camera dei Deputati) (1912). CDLX, $1^{\text {a }}$ tornata di materdi 11 giugno 1912, Seguito della discussione del disegno di legge: Sulla Cittadinanza, Atti Parlamentari, Prima Sessione, Discussioni-Prima tornata dell'11 giugno 1912, 20697-20716.

CD (1920). Disegno di legge presentato dal presidente del Consiglio dei Ministri Ministro dell'Interno (Giolitti) di concerto col Ministro degli Affari Esteri (Sforza)-Approvazione del Trattato di Rapallo ed annessione al Regno dei Territori attribuiti all'Italia. Doc. 950. Roma.

ICI (1908). Primo Congrersso degli Italiani all'Estero. Discorso inaugurale de IPresidente del 
Congresso Senatore Giacomo De Martino. Roma: Tipografia Cooperativa Sociale.

SR (Senato del Regno) (1910). Disegno di legge "Sulla cittadinanza" presentato dal Ministro di Grazia e Giustizia e dei Culti (Scialoja). Atti Parlamentari, Legislatura XXIII, 22 febbraio 1910, Prima Sessione, Documenti, Disegni di legge e Relazioni.

SR (1930). Legislatura XXVIII, $1^{\text {a }}$ Sessione 1929-1930, Documenti, Disegni di legge e Relazioni, Disegno di legge presentato dal Ministro della Giustizia e degli Affari di Culto (Rocco) di concerto col Capo del Governo Primo Ministro Segretario di Stato Ministro dell'Interno (Mussolini) col Ministro degli Affari Esteri (Grandi) col Ministro delle Colonie (De Bono) col Ministro della Guerra (Gazzerra) col Ministro della Marina (Sirianni) col Ministro dell'Aeronautica (Balbo) nella tornata del 7 marzo 1930-Anno VIII, Sulla cittadinanza, N. 394.

SR (1933). Relazione dell'Ufficio centrale, composta dai senatori D'Amelio, presidente, Di Donato, segretario, Mayer, Sandrini, Perla e Baccelli, relatore, nella tornata del 7 marzo 1930-Anno VIII, Presentata nella seduta del 31 marzo 1933-Anno XI, Sulla cittadinanza, N. 364-A.

Società Dante Alighieri (1909). Intervento del Relatore Avv. Valli, Roma, 22-25 settembre 1909. Roma.

Treaty of Saint-Germaine-en-Laye, 10/09/1919.

Treaty of Rapallo, 12/11/1920.

Laws quoted

Codice Civile del Regno d'Italia. Torino: Stamperia Reale, 1865.

Law No. 23, 31/01/1901, Legge sull'Emigrazione.

Law No. 217, 17/05/1906, Legge portante norme per la concessione della cittadinanza italiana.

Law No. 555, 13/06/1912, Sulla cittadinanza italiana.

Law No. 665, 30/06/1912, Contenente il nuovo testo unico della legge elettorale politica.

Law No. 108, 31/01/1926, Modificazioni ed Aggiunte alla legge $1 O$ Giugno 1912, N.555, Sulla Cittadinanza.

Law No. 1013, 26/06/1927, Legge organica per l'amministrazione della Tripolitania e della Cirenaica.

Law No. 999, 06/07/1933, Ordinamento organico per l'Eritrea e la Somalia.

Lieutenant Decree No. 920/1915, Proibizione nel Regno di vendite di immobili e altre operazioni a soggetti dell'Impero Austro-Ungarico durante la guerra.

Lieutenant Decree No. 1829, 28/11/1918, Relativo ai rapporti economici con gli Stati e i sudditi nemici.

Royal Decree No. 949, 02/08/1912, Norme per la esecuzione della L. 555/1912.

Royal Decree No. 315, 06/04/1913, Sulla sudditanza.

Royal Decree No. 931, 01/06/1919, Sulla cittadinanza e il governo della Tripolitania.

Royal Decree No. 2401, 31/10/1919, Sulla cittadinanza e il governo della Cirenaica.

Royal Decree No. 43, 29/01/1922, Che reca norme relative al conseguimento della cittadinanza italiana nelle nuove Provincie.

Royal Decree No. 1655, 18/11/1922, Regole per ottenere la cittadinanza italiana.

Royal Decree No. 1146, 22/07/1932, Obbligo per $i$ cittadini italiani libici della Tripolitania di prestare servizio militare in caso di mobilitazione.

Royal Decree No. 1997, 01/12/1934, Modificazioni alla legge 13 giugno 1912, n. 555, Sulla citta- 
dinanza.

Royal Decree No. 1728, 17/11/1938, Provvedimenti per la razza italiana.

Royal Decree No. 70, 09/01/1939, Aggregazione di Quattro province libiche al territorio del Regno d'Italia e concessione ai libici musulmani di una cittadinanza italiana speciale con statuto personale e successorio musulmano.

Royal Edict No. 680/1848, Regio Editto sulla legge elettorale.

Jurisprudence quoted

Appello Roma (1877). Alegiani c. Solfaroli, 21 febbraio 1877. Giurisprudenza Italiana, 29, 1, 2.

Submit or recommend next manuscript to SCIRP and we will provide best service for you:

Accepting pre-submission inquiries through Email, Facebook, LinkedIn, Twitter, etc. A wide selection of journals (inclusive of 9 subjects, more than 200 journals)

Providing 24-hour high-quality service

User-friendly online submission system

Fair and swift peer-review system

Efficient typesetting and proofreading procedure

Display of the result of downloads and visits, as well as the number of cited articles Maximum dissemination of your research work

Submit your manuscript at: http://papersubmission.scirp.org/ 